\title{
The Effect of Biochar on the Growth and N Fertilizer Requirement of Maize (Zea mays L.) in Green House Experiment
}

\author{
Widowati \\ Tribhuwana Tunggadewi University, Jl. Telaga Warna Blok C, Malang, Indonesia \\ W. H. Utomo (Corresponding author) \\ International Research Centre for Management of Degraded and Mining Land \\ University of Brawijaya, Malang, Indonesia \\ E-mail: hadi_utomo@hotmail.com \\ B. Guritno \\ Tuber and Root Crops Research Centre, University of Brawijaya, Malang, Indonesia
}

L. A. Soehono

Faculty of Science, University of Brawijaya, Malang, Indonesia

Received: February 6, 2012

doi:10.5539/jas.v4n5p255
Accepted: February 20, $2012 \quad$ Online Published: April 1, 2012

URL: http://dx.doi.org/10.5539/jas.v4n5p255

\begin{abstract}
Greenhouse experiments were carried out to study the effect of biochar and other organic amendment (Chicken Manure, $\mathrm{CM}$; and City waste compost, $\mathrm{CW}$ ) using on the growth and $\mathrm{N}$ fertilizer requirement of maize. The first experiment was carried out to study the effect of biochar application to maize growth, and then continued to study the residual effect of biochar. The second experiment was carried out to study the effect of biochar application on nitrogen fertilizer requirement. The results show that the first season of maize biomass of organic amendment of treated soils did not significantly different from no organic amendment. However, organic amendment improved soil fertility status, especially increasing C-organic, N, K and CEC. The biomass of the second season maize of biochar of treated soil was higher compared to the other treatments. The second experiment shows that biochar application decreased $\mathrm{N}$ fertilizer requirement. To produce $3.23 \mathrm{Mg} \mathrm{ha}^{-1}$ biomass, it required $90 \mathrm{~kg} \mathrm{ha}^{-1} \mathrm{~N}$ for $15 \mathrm{Mg} \mathrm{ha}^{-1} \mathrm{CM}$ biochar treated soil, and $160 \mathrm{~kg} \mathrm{ha}^{-1}$ for the non treated soil.
\end{abstract}

Keywords: Chicken manure, Poultry litter, Compost, Nitrogen efficiency, Organic amendments

\section{Introduction}

Since green revolution, it seems that application of inorganic fertilizer is hardly avoided in increasing crop production. The advantage of inorganic fertilizers, indeed, has been proven widely to have very spectacular results. It is able to make the production doubled, or even tripled compared to world crop production. However, the phenomena of decreasing soil quality, on the other hand to obtain the same yield, the rate of inorganic fertilizer application steadily increases from year to year. The application of chemical fertilizer is not also capable of maintaining yield increase (Islami et al., 2011). In line with that, it has been widely realized that application of excessive inorganic fertilizer, especially nitrogen, causes soil deterioration and many environmental problems (Haynes \& Naidu, 1998; Liu et al., 2010; Vitosuek et al., 1997).

The common technology for increasing fertilizer efficiency is integrated crop management which includes the application of organic manure and other organic materials to soil (Fageria \& Baligar, 2005). However, it is known that under wet tropical condition, organic materials put into the soil will be decomposed very rapidly. It makes addition of organic materials will be done in a very high dosage and repeated yearly. In addition, to make 
higher cost of organic materials application, it is now realized that the rapid decomposition and mineralization of organic materials have a significant contribution to global warming (Jenkinson et al., 1991).

By realizing those problems; some previous researchers try to use the more resistant organic matter such as "char" as the sources of soil organic materials applied to soil (Lehman et al., 2003). This material, which is known as "agrichar" or more commonly term "biochar" has been proven to have the same positive as the organic manure or other organic materials as a soil amendment (Wolf et al., 2008). A lot of works have shown that biochar is able to improve soil properties, included soil pH, and CEC (Chan et al., 2008; Masulili et al., 2010), soil aggregation, soil water holding capacity and soil strength (Chan et al., 2008), and to increase soil biology population and activity (Rondon et al., 2007) . Observation of Steiner et al. (2007) indicates that in the long term, application of biochar increases plant nutrient availability and soil productivity. Increasing of crop yield with biochar application has been shown by Islami et al., (2011a), Sukartono et al., (2011) and Yamato et al., (2004) for maize (Zea mays L.); Tagoe et al., (2008) for soybean (Glicine max (L) Merr.); and Islami et al., (2011b) for cassava (Manihot esculenta $\mathrm{Cranz}$ ).

One of the reasons for increasing crop yield with biochar application is the increasing of nitrogen utilization from the applied fertilizer (Steiner et al., 2007; Widowati et al., 2011). This is as the result from the decrease of nitrogen lost due the increase of soil CEC with biochar application (Chan et al., 2008; Masulili et al., 2010) or because of the biochar ability to inhibit N-NO3 transformation from N-NH4 released by fertilizer (Widowati et al., 2011). The experiment reported here is aimed to know the possibility of decreasing nitrogen fertilizer requirement of maize with biochar application. The hypothesis behind this study is "if there is decrease in nitrogen loss due biochar application, then there is less nitrogen requirement to produce the same yield with that of obtained by the soil with no biochar application".

\section{Materials and Methods}

The experiments were carried out in the green house of Tribhuwana Tunggadewi University, Malang, Indonesia $\left(7^{\circ} .48^{\prime} .50^{\prime \prime}\right.$ South and $112^{\circ} .37^{\prime} 41^{\prime \prime}$ East). During the experimental period the daily temperature varied from about $16^{\circ} \mathrm{C}-36^{\circ} \mathrm{C}$ with relative humidity of about 43-86\%, and light intensity of 365-1997 lux).

Biochar was prepared by pyrolysis method as described by Masulili et al. (2010) with chicken manure and city waste as the feedstuffs. The chicken manure, consisted of sawdust materials and chicken manure, was collected from P.T. Charoen Pokhand Poultry enterprises and the city waste, consisted of plant materials and other organic waste, was collected from city waste collector of Malang city, Indonesia. These materials were sun dried to reach water content of about $17 \%$ and then heated in the pyrolysis reactor at temperature of $500^{\circ} \mathrm{C}$ for 2 hours 30 minutes for poultry litter (then it was called as chicken manure, CM, biochar) and 2 hours 5 minutes for city waste (then it was called as city waste, $\mathrm{CW}$, biochar).

Biochar characteristics were analyzed by the method as described by Masulili et al. (2010). The characteristics of these biochars, together with their feedstuffs poultry litter and city waste, and the soil used for experiment are presented in Table 1.

$<$ Table 1>

The studies consisted of two experiments; the first experiment was aimed to study the effect of biochar on maize growth, nitrogen absorption and soil nitrogen content after maize harvesting, and the second experiment was carried out to study the effect of biochar application on nitrogen fertilizer requirement. The treatments of the first experiment were: (1) control (without nitrogen fertilizer and without organic amendment), (2) $145 \mathrm{~kg} \mathrm{ha}^{-1} \mathrm{~N}$ without organic amendment ( $\mathrm{N}-\mathrm{No} \mathrm{OM})$, (3) $145 \mathrm{~kg} \mathrm{ha}^{-1} \mathrm{~N}$ with addition of $50 \mathrm{Mg} \mathrm{ha}^{-1}$ chicken manure (N+CM), (4) $145 \mathrm{~kg} \mathrm{ha}^{-1} \mathrm{~N}$ with addition of $50 \mathrm{Mg} \mathrm{ha}^{-1}$ city waste compost ( $\mathrm{N}+\mathrm{CW}$ compost), (5) $145 \mathrm{~kg} \mathrm{ha}^{-1} \mathrm{~N}$ with addition of $30 \mathrm{Mg} \mathrm{ha}^{-1}$ chicken manure biochar (N+CM biochar), (6) $145 \mathrm{~kg} \mathrm{ha}^{-1} \mathrm{~N}$ with addition of $30 \mathrm{Mg} \mathrm{ha}^{-1}$ city waste biochar $\left(\mathrm{N}+\mathrm{CW}\right.$ biochar). All treatments were fertilized with $50 \mathrm{~kg} \mathrm{ha}^{-1} \mathrm{P}_{2} \mathrm{O}_{5}$ and $50 \mathrm{~kg} \mathrm{ha}^{-1} \mathrm{~K}_{2} \mathrm{O}$. Biochar and fertilizer rate were calculated based on area of plastic poly bag used for growing the maize, and these 6 treatments were arranged in Completely Randomized Design with 4 replications and plant distance of 0.5 m X $0.5 \mathrm{~m}$. The maize was planted on 5 June 2010 and harvested on 10 August 2010. To study the residual effect of biochar application, the second maize was grown on 5 September 2010 and harvested on 10 November 2010.

The treatments for the second experiment consisted of 5 levels on nitrogen fertilizer $(0 ; 45 ; 90,135$ and $180 \mathrm{~kg}$ $\left.\mathrm{ha}^{-1} \mathrm{~N}\right)$, and 4 levels of CM biochar $\left(0 ; 15 ; 30\right.$ and $\left.60 \mathrm{Mg} \mathrm{ha}^{-1}\right)$. These 20 treatment combinations were arranged in Completely Randomized Design with 3 replications. The maize was planted on 5 December 2010 and harvested on 10 February 2011. 
The plastic poly bag of about $45 \mathrm{~kg}$ capacity with surface diameter of about $30 \mathrm{~cm}$ was filled with about $37 \mathrm{~kg}$ air dried soil, then biochar was applied and mixed to a depth of about $20 \mathrm{~cm}$, after which it was watered to about field capacity and incubated for 7 days. Two seeds of maize, Bisma cv, were planted in each plastic poly bag, and after 2 weeks the maize was thinned left 1 plant/poly bag. All P, K and 1/3 N rate fertilizers were applied at the planting date, and $2 / 3$ of $\mathrm{N}$ rate was applied at 30 days after planting. The maize was watered every 3 days to water content of field capacity, and it was harvested at the end of vegetative growth (65 days).

The data collected were: plant height, stem diameter, dry biomass, root length, nitrogen absorption, and soil properties which include organic $\mathrm{C}$ content, nitrogen content, and Cation Exchange Capacity (CEC). Plant height was measured from the soil surface to the highest part of the plant. Dry biomass determination was done by cutting above ground plant, and after which the plant was oven dried at temperature of $80^{\circ} \mathrm{C}$ until it reached constant weight). Root length determination was done by measured all root with the methods of mapping.

Total plant nitrogen was extracted with wet sulfuric acid digestion (Horneck \& Miller, 1998) and the nitrogen content in the sample was determined by Kjeldahl method. Then the efficiency of nitrogen fertilization was calculated by equation:

$\mathrm{F}_{\text {eff }}=(\mathrm{N}$ absorption of the desired maize treatment $-\mathrm{N}$ absorption of maize the control $) \times 100 \%$

\section{Applied $\mathrm{N}$}

Soil organic C content was determined by Walkley and Black wet oxidation method (Soil Survey Laboratory Staff, 1992), nitrogen by Kjeldahl method (Bremner and Mulvaeny, 1982), and CEC was extracted by 1M $\mathrm{NH}_{4} \mathrm{Oac}$ (buffered at $\mathrm{pH}$ 7.0), and exchangeable bases in the solutions were measured using AAS (Shimatzu). Available $\mathrm{P}$ was determined by Bray 1 solution.

ANOVA was used for analyzing the data, and if there was significant different, further analysis was done with LSD 5\%.

\section{Results and Discussion}

Nitrogen application, both with and without organic amendment addition, improved plant growth by increasing plant height, stem diameter, root length and dry biomass of maize harvested at the end of vegetative growth (Table 2). Compared to $\mathrm{N}$ application only, addition of organic amendments increased root length, but did not significantly influence, plant height, stem diameter, and dry biomass. The same phenomenon was found for total nitrogen absorption. This result indicated the main limiting factors to increase biomass yield in the soil used for the study was nitrogen. Addition of $135 \mathrm{~kg} \mathrm{ha}^{-1} \mathrm{~N}$ was enough to produce maize dry biomass of about $3 \mathrm{Mg} \mathrm{ha} \mathrm{M}^{-1}$. Therefore, any addition of plant nutrient from organic amendments (Table 3; see also Widowati et al., 2011) did not improve (compared to $\mathrm{N}$ treatment) maize growth. The increase in root length with organic matter amendments was probably due the improvement of some soil physical properties, as has been suggested by Chan et al. (2008).

\section{$<$ Table 2>}

Nitrogen application increased nitrogen absorption (Table 2). Addition of organic amendment to this applied maize nitrogen did not significantly influence nitrogen absorption. The absorption of nitrogen of fertilized maize crops varies from $62.45 \mathrm{~kg} \mathrm{ha}^{-1}$ (nitrogen applied only) to $67.50 \mathrm{~kg} \mathrm{ha}^{-1}$ ( $\mathrm{N}+$ chicken manure) with the nitrogen absorption of $33.07 \mathrm{~kg} \mathrm{ha}^{-1}$ for the control treatment (No N No OM).

The result (Table 2 ) shows that the highest fertilizer efficiency was $(25.50 \%)$ obtained by CM treatment. This figure does not necessarily reflect the real efficiency of CM treatment; because in this treatment the soil would get a higher nitrogen addition from the manure (see Table 1).

From biomass yield point of view, the growth of the second maize in the soil treated with biochar was better than the $\mathrm{N}$ treated soil (No OM). The result presented in Table 3 shows that the soil treated with biochar produced dry biomass of $3.34 \mathrm{Mg} \mathrm{ha}^{-1}$ (CM biochar) and $3.30 \mathrm{Mg} \mathrm{ha}^{-1}$ (CW biochar) which were significantly higher than maize biomass produced by N-No OM $\left(2.39 \mathrm{Mg} \mathrm{ha}^{-1}\right)$. The second maize biomass produced by CM and CW compost treated soil, on the other hand, did not significantly different from maize biomass produced by N-No OM treated soil. This result indicated that there was a significant residual effect of biochar on the second maize growth, but not with CM and CW compost. Looking from soil properties (Table 4), this growth improvement could be explained from the higher nutrient availability in biochar treated soil, especially $\mathrm{N}$ and $\mathrm{K}$.

$<$ Table 3>

The higher nitrogen in organic amendment treated soil (compared to that of in the $\mathrm{N}$ only treated soil and the control) could originated from the nitrogen in the material it self (see Table 1), and to some extent caused by a 
lower of nitrogen leaching due increasing of soil cation exchange capacity (e.g. Masulili et al., 2010; Liang et al.,

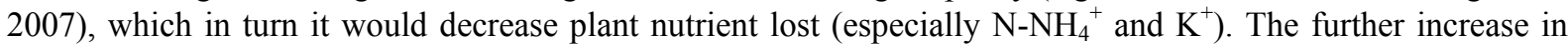
soil nitrogen content in the biochar treated soil could be originated from retardation of $\mathrm{N}^{-\mathrm{NH}_{4}}{ }^{+}$to $\mathrm{N}^{-\mathrm{NO}_{3}}{ }^{-}$ transformation in biochar treated soil (Widowati et al., 2011) which will further lowered nitrogen leaching.

The results in Table 3 also shows that soil organic-C in biochar treated soils were higher compared to chicken manure and city waste compost. This result indicated that biochar is organic material that resistant to decomposition as suggested by the previous workers (e.g. Lehman et al., 2003; Chan et al., 2008). Furthermore, the data in Table 4 show that amendment application increased available $\mathrm{P}$, exchangeable $\mathrm{K}$, CEC and soil porosity at the harvesting of the first maize, but did not influence soil aggregation. The increase in soil $\mathrm{P}$ and $\mathrm{K}$ was thought originated from the $\mathrm{P}$ and $\mathrm{K}$ in material itself (Table 1), and the increase of CEC could be explained from phenolic and carboxyl groups in the organic amendment. After harvesting the second maize, organic $\mathrm{C}$ of $\mathrm{CM}$ treated soil did not significantly different from the control or N-No OM treated soils. This result indicated that Chicken Manure almost completely decomposed during this study (2 maize growing seasons). The biochar treated soils, on the other hand, had a significantly higher C-organic compared to other treatments. The biochar treated soils also possessed a higher N, exchangeable $\mathrm{K}$ and CEC.

$<$ Table 4>

The result presented in Table 5 show that there was an interaction between biochar and nitrogen fertilization to maize biomass yield. Application of biochar without nitrogen fertilizer increased biomass yield from $1.81 \mathrm{Mg}$ $\mathrm{ha}^{-1}$ (without biochar) to $2.75 \mathrm{Mg} \mathrm{ha}^{-1}$ (60 Mg ha ${ }^{-1}$ biochar). This increase could be come from the addition of plant nutrient from CM biochar, The data presented in Table 1 show that $\mathrm{N}$-total in CM biochar is $1.9 \%$, hence with $60 \mathrm{Mg} \mathrm{ha}^{-1} \mathrm{CM}$ biochar, there would be an addition of about $190 \mathrm{~kg} \mathrm{ha}^{-1} \mathrm{~N}$. It is understood that not all of these nitrogen are in the form of available nitrogen, but surely some of these nitrogen could be used for maize growth. The highest maize biomass was about $3.30 \mathrm{Mg} \mathrm{ha}^{-1}$, which obtained by $90 \mathrm{~kg} \mathrm{ha}^{-1} \mathrm{~N}$ application on the $15 \mathrm{Mg} \mathrm{ha}^{-1} \mathrm{CM}$ biochar treated soil. If the soil was not treated with $\mathrm{CM}$ biochar, this biomass yield was obtained by $180 \mathrm{~kg} \mathrm{ha}^{-1} \mathrm{~N}$ application. Thus application of CM biochar reduced nitrogen fertilizer requirement of maize. The reduction of nitrogen in this study would, partly come from the addition on $\mathrm{N}$ from CM biochar (see Table 1), and to some extend the decrease of nitrogen lost with biochar application (Widowati et al., 2011).

$<$ Table 5>

To calculate the nitrogen requirement at any biochar rate, the data in Table 5 was analyzed with surface curve response, and the resulted equation is (see also Fig. 1):

$$
\mathrm{Y}=1,691+0,0192 \mathrm{~N}+0,0273 \mathrm{~B}-0,000060 \mathrm{~N}^{2}-0,000205 \mathrm{~B}^{2}-0,000094 \mathrm{NB}
$$

In which $\mathrm{Y}$ is maize biomass yield $\left(\mathrm{Mg} \mathrm{ha}^{-1}\right), \mathrm{N}$ is nitrogen rate $\left(\mathrm{kg} \mathrm{ha}^{-1}\right)$, and $\mathrm{B}$ is biochar rate $\left(\mathrm{Mg} \mathrm{ha}^{-1}\right)$.

With this equation we can calculate that with no biochar application, the highest maize biomass was obtained at $160 \mathrm{~kg} \mathrm{ha}^{-1} \mathrm{~N}$ which would produce $3.22 \mathrm{Mg} \mathrm{ha}^{-1}$ maize biomass, and further increasing $\mathrm{N}$ rate would decrease the maize yield. In $15 \mathrm{Mg} \mathrm{ha}^{-1} \mathrm{CM}$ biochar treated soil, this biomass yield could be obtained by $90 \mathrm{~kg} \mathrm{ha}^{-1} \mathrm{~N}$. The highest biomass yield in this treatment was $3.37 \mathrm{Mg} \mathrm{ha}^{-1}$ which obtained by $140 \mathrm{~kg} \mathrm{ha}^{-1} \mathrm{~N}$ application.

\section{Conclusions}

The results of this study shows that the application of Nitrogen fertilizer, either with or without organic matter amendment increases maize biomass yield. The maize biomass of the first season maize of organic amendment treated soils does not significantly different with that of no organic amendment. However, organic amendment improves soil fertility status, especially increasing C-organic, N, K and CEC. The biomass of the second season maize of biochar treated soil is higher compared to the other treatments. The second experiment shows that biochar application decreases $\mathrm{N}$ fertilizer requirement. To produce $3.23 \mathrm{Mg} \mathrm{ha}^{-1}$ biomass, it requires $90 \mathrm{~kg} \mathrm{ha}^{-1} \mathrm{~N}$ for $15 \mathrm{Mg} \mathrm{ha}{ }^{-1} \mathrm{CM}$ biochar treated soil, and $160 \mathrm{~kg} \mathrm{ha}^{-1}$ for the non treated soil.

It shall be kept in mind that this conclusion is based on the green house condition. Therefore, any extrapolation to the field shall consider the field condition.

\section{References}

Bremner, J. M., \& Mulvaney, C. S. (1982). Nitrogen-total. In: A.L. Page, R.H. Miller, \& D.R. Keeney, (Eds.), Methods of Soil Analyses, Part 2. Chemical and Mineralogical properties, pp: 595-624. Madison: American Society of Agronomy and Soil Science Society of America Inc.

Chan, K. Y., Van Zwieten, B. L., Meszaros, I., Downie, D. \& Joseph, S.(2008). Using poultry litter biochars as soil amendments. Australian Journal of Soil Research, 46, 437- 444. 
Fageria, N. K. \& Baligar, V. C. (2005). Enhancing nitrogen use efficiency in crop plants. Advances in Agronomy, $88,97-185$.

Haines, R. J. \& Naidu, R. (1998). Influence of lime, fertilizer and organic manure on soil organic matter application and soil physical conditions. Nutrient Cycling in Agroecosystems, 51, 123-137.

Jenkinson, D. S., Adams, D. E. \& Wild, A. (1991). Model estimate of CO2 from soil in respons to global warming. Nature, 351, 304-306.

Islami, T., Guritno, B., Nurbasuki \& Suryanto, A. (2011a). Maize yield and associated soil quality changes in cassava + maize intercropping system after 3 years of biochar application. Journal of Agriculture and Food Technology, 1, 112-115.

Islami, T., Guritno, B., Nurbasuki \& Suryanto, A. (2011b). Biochar for cassava based cropping system in the degraded lands of East Java, Indonesia. Journal of Tropical Agriculture, 49, 40- 46.

Lehman, J., da Silva Jr., J. P., Steiner, C., Nehls, T., Zech, W. \& Glaser, B. (2003). Nutrient availability and leaching in an archaeological Anthrosol and a Ferralsol of the Central Amazon basin: fertilizer, manure and charcoal amendments. Plant Soil, 249, 343-357. http://dx.doi.org/10.1023/A:1022833116184

Liang, B., Lehmann, J., Kinyangi, D., Grossman, J., O’Neill, B., Skjemstad, J. O., Thies, J., Luizao, F. J., Peterson, J., \& Neves, E. G. (2006). Black carbon increases cation exchange capacity in soils. Soil Science Society of America, 70, 1719-1730. http://dx.doi.org/10.2136/sssaj2005.0383

Liu, E., Changrong, Y., Xurong, M., Wenqing, H., So, H. B., Linping, D., Qin, L., Shuang L. \& Tinglu, F. (2010). Long term effect of chemical fertilizer, straw, and manure on soil chemical and biological properties in north-west China. Geoderma, 150, 173-180.

Masulili, A., Utomo, W. H. \& Syekhfani. (2010). Rice husk biochar for rice based cropping system in acid soil 1. The characteristics of rice husk biochar and its Influence on the properties of acid sulfate soils and rice growth in West Kalimantan, Indonesia. Journal of Agriculture Science (Canada), 3, 25-33.

Rondon, M. A., Lehmann, J., Ramirez, J. \& Hurtado, M. (2007). Biological nitrogen fixation by common beans (Phaseolus vulgaris L.) increases with biochar additions. Biology and Fertility of Soils, 43, 699-708. http://dx.doi.org/10.1007/s00374-006-0152-z

Soil Survey Laboratory Staff. (1992). Soil survey laboratory methods manual. Soil Survey Investigation Report No. 42, Version 2.0, USDA.

Steiner, C., Teixeira, W.G., Lehmann, J., Nehls, T., de Macedo, J. L. V., Blum, W. E. H.,\& Zech, W. (2007). Long effect of manure, charcoal and mineral fertilization on crop production and fertility on highly weathered central amazonian upland soil. Plant Soil, 291, 275-290.

Sukartono, Utomo, W. H., Kusuma, Z. \& Nugroho, W. H. (2011). Soil fertility status, nutrient uptake, and maize (Zea mays L.) yield following biochar application on sandy soils of Lombok, Indonesia. Journal of Tropical Agriculture, 49, 47-52.

Tagoe, S. O., Horiuchi, T. \& Matsui, T. (2008). Effects of carbonized and dried chicken manures on the growth, yield, and N content of soybean. Plant Soil, 306, 211- 220.

Vitousek, P. M., Aber, J. D., Howarth, R. W., Likens, G. E., Matson, P. A., Schindler, D. W., Schlesinger, W. H. \& Tilman, D. G. (1997). Human alteration of the global nitrogen cycle: Sources and consequences. Ecological Applications, 737-750.

Widowati, Utomo, W. H., Soehono, L. A. \& Guritno, B. (2011). Effect of biochar on the release and loss of nitrogen from urea fertilization. Journal of Agriculture and Food Technology, 1, 127-132.

Woolf, D. (2008). Biochar as a soil amendment: A review of the environmental implications. http://orgprints.org/13268/01/Biochar_as_a_soil_amendment_-_a_review.pdf. Retrieved via Internet Explorer Ver. 6, 2 October 2008.

Yamato, M., Okimori, Y., Wibowo, I. F., Anshori, S. \& Ogawa, M. (2008). Effects of the application of charred bark of Acacia mangium on the yield of maize, cowpea and peanut, and soil chemical properties in South Sumatra, Indonesia. Soil Science and Plant Nutrition, 52, 489- 495. 
Table 1. Some characteristics of soil and organic amendments used in the experiments

\begin{tabular}{|l|c|c|c|c|c|}
\hline Characteristics & \multicolumn{1}{|l|}{ Soil } & Chicken manure & CW compost & CM biochar & CW biochar \\
& & & & & \\
$\mathrm{pH} \mathrm{H} \mathrm{H}_{2} \mathrm{O}$ & 6.37 & 7.1 & 7.9 & 9.0 & 9.6 \\
Organic-C (\%) & 1.46 & 17.61 & 21.43 & 28.13 & 31.41 \\
$\mathrm{~N}$ Total (\%) & 0.19 & 2.02 & 1.81 & 1.9 & 1.67 \\
$\mathrm{C} / \mathrm{N}$ & 7 & 8 & 11 & 10 & 18 \\
$\mathrm{P}(\%)$ & 24.38 & 2.77 & 0.35 & 3.77 & 0.72 \\
$\mathrm{~K}(\%)$ & 0.75 & 2.44 & 0.82 & 1.48 & 0.93 \\
$\mathrm{CEC}\left(\mathrm{cmol} \mathrm{kg}{ }^{-1}\right)$ & 14.02 & - & - & 17.48 & 23.87 \\
Clay (\%) & 23.67 & - & - & - & - \\
Sand (\%) & 21 & - & - & - & - \\
\hline
\end{tabular}

1) the units of available $\mathrm{P}$ (Bray 1) in the soil is $\mathrm{mg} \mathrm{kg}^{-1}$; and for the exchangeable $\mathrm{K}_{\text {is }} \mathrm{cmol} \mathrm{kg}^{-}{ }^{1}$

Table 2. Effect of biochar on maize height, stem diameter, root length and dry biomass, and nitrogen absorption at the end of vegetative growth (first season maize)

\begin{tabular}{|l|c|c|c|c|c|c|}
\hline & $\begin{array}{l}\text { Plant } \\
\text { height } \\
(\mathrm{cm})\end{array}$ & $\begin{array}{l}\text { Stem } \\
\text { diameter } \\
(\mathrm{cm})\end{array}$ & $\begin{array}{l}\text { Root } \\
\text { length } \\
(\mathrm{cm} \\
\left.\text { plant }^{-1}\right)\end{array}$ & $\begin{array}{l}\text { Dry } \\
\text { biomass } \\
\left(\mathrm{Mg} \mathrm{ha}^{-1}\right)\end{array}$ & $\begin{array}{l}\text { Total } \\
\text { nitrogen } \\
\text { absorption } \\
\left(\mathrm{kg} \mathrm{ha}^{-1}\right)\end{array}$ & $\begin{array}{l}\text { Efficiency } \\
\text { of N } \\
\text { fertilization } \\
(\%)\end{array}$ \\
\hline Control & $99.76 \mathrm{a}$ & $1.85 \mathrm{a}$ & $1.25 \mathrm{a}$ & $1.89 \mathrm{a}$ & $33.07 \mathrm{a}$ & - \\
N-No OM & $119.67 \mathrm{~b}$ & $1.98 \mathrm{ab}$ & $1.62 \mathrm{~b}$ & $3.06 \mathrm{~b}$ & $62.45 \mathrm{~b}$ & $21.76 \mathrm{a}$ \\
$\mathrm{N}+$ Chicken manure & $125.64 \mathrm{~b}$ & $2.15 \mathrm{~b}$ & $2.30 \mathrm{~d}$ & $3.29 \mathrm{~b}$ & $67.50 \mathrm{~b}$ & $25.50 \mathrm{~b}$ \\
$\mathrm{~N}+$ City waste compost & $123.27 \mathrm{~b}$ & $2.11 \mathrm{~b}$ & $1.95 \mathrm{c}$ & $3.08 \mathrm{~b}$ & $63.62 \mathrm{~b}$ & $22.62 \mathrm{ab}$ \\
$\mathrm{N}+\mathrm{CM}$ biochar & $120.39 \mathrm{~b}$ & $2.10 \mathrm{~b}$ & $2.18 \mathrm{~cd}$ & $3.09 \mathrm{~b}$ & $63.84 \mathrm{~b}$ & $22.79 \mathrm{ab}$ \\
\hline N+CW biochar & $123.42 \mathrm{~b}$ & $2.01 \mathrm{ab}$ & $2.15 \mathrm{~cd}$ & $3.11 \mathrm{~b}$ & $63.46 \mathrm{~b}$ & $22.51 \mathrm{ab}$ \\
\hline
\end{tabular}

1) means followed by the same letters in the same column are not significantly different ( $\mathrm{p}=0.05 \%)$

Table 3. Residual effect of biochar application on maize height, stem diameter, root length, dry biomass, and nitrogen absorption at the end of vegetative growth

\begin{tabular}{|l|c|c|c|c|c|c|}
\hline Treatment & $\begin{array}{c}\text { Plant } \\
\text { height } \\
(\mathrm{cm})\end{array}$ & $\begin{array}{c}\text { Stem } \\
\text { diameter } \\
(\mathrm{cm})\end{array}$ & $\begin{array}{l}\text { Root } \\
\text { length }(\mathrm{cm} \\
\left.\text { plant }^{-1}\right)\end{array}$ & $\begin{array}{l}\text { Dry } \\
\text { biomass } \\
\left(\mathrm{Mg} \mathrm{h}^{-1}\right)\end{array}$ & $\begin{array}{l}\text { Total } \\
\text { nitrogen } \\
\text { absorption } \\
\left(\mathrm{kg} \mathrm{h}^{-1}\right)\end{array}$ & $\begin{array}{l}\text { Efficiency } \\
\text { of N } \\
\text { fertilization } \\
(\%)\end{array}$ \\
\hline Control & 87.75 & $1.74 \mathrm{a}$ & $1.05 \mathrm{a}$ & $1.68 \mathrm{a}$ & $33.09 \mathrm{a}$ & - \\
N-No OM & $123.62 \mathrm{~b}$ & $2.05 \mathrm{ab}$ & $1.45 \mathrm{c}$ & $2.39 \mathrm{~b}$ & $54.25 \mathrm{~b}$ & $15.67 \mathrm{a}$ \\
$\mathrm{N}+$ Chicken manure & $123.47 \mathrm{~b}$ & $2.45 \mathrm{~b}$ & $1.30 \mathrm{bc}$ & $2.97 \mathrm{bc}$ & $65.63 \mathrm{c}$ & $24.10 \mathrm{~b}$ \\
$\mathrm{~N}+$ City waste compost & $123.20 \mathrm{~b}$ & $2.43 \mathrm{~b}$ & $1.24 \mathrm{ab}$ & $2.85 \mathrm{~b}$ & $64.12 \mathrm{c}$ & $22.98 \mathrm{ab}$ \\
$\mathrm{N}+\mathrm{CM}$ biochar & $124.35 \mathrm{~b}$ & $2.38 \mathrm{~b}$ & $2.07 \mathrm{~d}$ & $3.34 \mathrm{c}$ & $88.17 \mathrm{~d}$ & $40.80 \mathrm{c}$ \\
\hline $\mathrm{N}+\mathrm{CW}$ biochar & $117.37 \mathrm{~b}$ & $2.41 \mathrm{~b}$ & $2.20 \mathrm{~d}$ & $3.30 \mathrm{c}$ & $85.47 \mathrm{~d}$ & $38.80 \mathrm{c}$ \\
\hline
\end{tabular}

*) means followed by the same letters in the same column are not significantly different $(p=0,05)$ 
Table 4. Effect of biochar on some soil properties after the harvesting the first and second maize

\begin{tabular}{|c|c|c|c|c|c|c|c|c|c|c|}
\hline \multirow[t]{2}{*}{ Treatment } & \multicolumn{2}{|c|}{$\begin{array}{l}\text { Organic-C } \\
\qquad(\%)\end{array}$} & \multicolumn{2}{|c|}{$\begin{array}{l}\mathrm{N} \\
(\%)\end{array}$} & \multicolumn{2}{|c|}{$\begin{array}{l}\text { Available P } \\
\text { (ppm) }\end{array}$} & \multicolumn{2}{|c|}{$\begin{array}{c}\text { Exchangeable } \mathrm{K} \\
\left(\mathrm{cmol} \mathrm{kg}^{-1}\right)\end{array}$} & \multicolumn{2}{|c|}{$\begin{array}{c}\mathrm{CEC} \\
\left(\mathrm{cmol} \mathrm{kg}^{-1}\right)\end{array}$} \\
\hline & $1^{\text {st }}$ & $2^{\text {nd }}$ & $1^{\text {st }}$ & $2^{\text {nd }}$ & $1^{\text {st }}$ & $2^{\text {nd }}$ & $1^{\text {st }}$ & $2^{\text {nd }}$ & $1^{\text {st }}$ & $2^{\text {nd }}$ \\
\hline Control & $1.39 \mathrm{a}$ & $1.20 \mathrm{a}$ & $0.11 \mathrm{a}$ & $0.09 \mathrm{a}$ & $21.56 \mathrm{a}$ & $19.45 \mathrm{a}$ & $0.67 \mathrm{a}$ & $0.69 \mathrm{a}$ & $14.14 \mathrm{a}$ & $13.22 \mathrm{a}$ \\
\hline N-No OM & $1.41 \mathrm{a}$ & $1.15 \mathrm{a}$ & $0.18 \mathrm{ab}$ & $0.17 \mathrm{ab}$ & $22.54 \mathrm{a}$ & $23.54 \mathrm{ab}$ & $0.75 \mathrm{a}$ & $0.74 \mathrm{ab}$ & $13.78 \mathrm{a}$ & $14.18 \mathrm{a}$ \\
\hline $\mathrm{N}+$ Chicken manure & $2.28 \mathrm{~b}$ & $1.98 \mathrm{ab}$ & $0.25 \mathrm{~b}$ & $0.20 \mathrm{~b}$ & $36.25 \mathrm{~b}$ & $26.28 \mathrm{~b}$ & $1.16 \mathrm{ab}$ & $1.05 \mathrm{ab}$ & $17.24 \mathrm{ab}$ & $16.20 \mathrm{ab}$ \\
\hline $\mathrm{N}+$ City waste compost & $2.46 \mathrm{~b}$ & $2.06 \mathrm{~b}$ & $0.29 \mathrm{~b}$ & $0.21 \mathrm{bc}$ & $34.76 \mathrm{~b}$ & $27.78 \mathrm{~b}$ & $1.45 \mathrm{bc}$ & $1.19 \mathrm{bc}$ & $16.25 \mathrm{ab}$ & $17.30 \mathrm{ab}$ \\
\hline $\mathrm{N}+\mathrm{CM}$ biochar & $3.14 \mathrm{~d}$ & $3.14 \mathrm{c}$ & $0.24 \mathrm{~b}$ & $0.39 \mathrm{c}$ & $40.26 \mathrm{~b}$ & $29.45 \mathrm{~b}$ & $1.98 \mathrm{c}$ & $2.18 \mathrm{c}$ & $19.27 \mathrm{~b}$ & $19.27 \mathrm{~b}$ \\
\hline $\mathrm{N}+\mathrm{CW}$ biochar & $3.21 \mathrm{~d}$ & $3.18 \mathrm{c}$ & $0.21 \mathrm{~b}$ & $0.31 \mathrm{c}$ & $38.76 \mathrm{~b}$ & $30.04 \mathrm{~b}$ & $2.01 \mathrm{c}$ & $2.14 \mathrm{c}$ & $19.68 \mathrm{~b}$ & $18.34 \mathrm{~b}$ \\
\hline
\end{tabular}

1) Means followed by the same letters in the same column are not significantly different $(\mathrm{p}=0,05)$

Table 5. Effect of FYM biochar and nitrogen application on maize biomass $\left(\mathrm{Mg} \mathrm{ha}^{-1}\right)$ at the end of vegetative growth

\begin{tabular}{|c|c|c|c|c|c|}
\hline \multicolumn{2}{|c|}{ CM biochar } & \multicolumn{5}{|c|}{$\mathrm{N}$ fertilizer $\left(\mathrm{kg} \mathrm{ha}^{-1}\right)$} \\
\cline { 2 - 6 }$\left(\mathrm{Mg} \mathrm{ha}^{-1}\right)$ & 0 & 45 & 90 & 135 & 180 \\
\hline 0 & $1.61 \mathrm{a}$ & $2.13 \mathrm{~b}$ & $3.11 \mathrm{de}$ & $3.13 \mathrm{def}$ & $3.23 \mathrm{ef}$ \\
15 & $2.06 \mathrm{~b}$ & $3.32 \mathrm{f}$ & $3.31 \mathrm{ef}$ & $3.29 \mathrm{ef}$ & $3.30 \mathrm{ef}$ \\
30 & $2.11 \mathrm{~b}$ & $2.99 \mathrm{~d}$ & $3.26 \mathrm{ef}$ & $3.24 \mathrm{ef}$ & $3.28 \mathrm{ef}$ \\
60 & $2.75 \mathrm{c}$ & $3.00 \mathrm{~d}$ & $3.19 \mathrm{def}$ & $3.28 \mathrm{ef}$ & $3.29 \mathrm{ef}$ \\
\hline
\end{tabular}

Means followed by the same letters are not significantly different $(\mathrm{p}=0,05)$ 


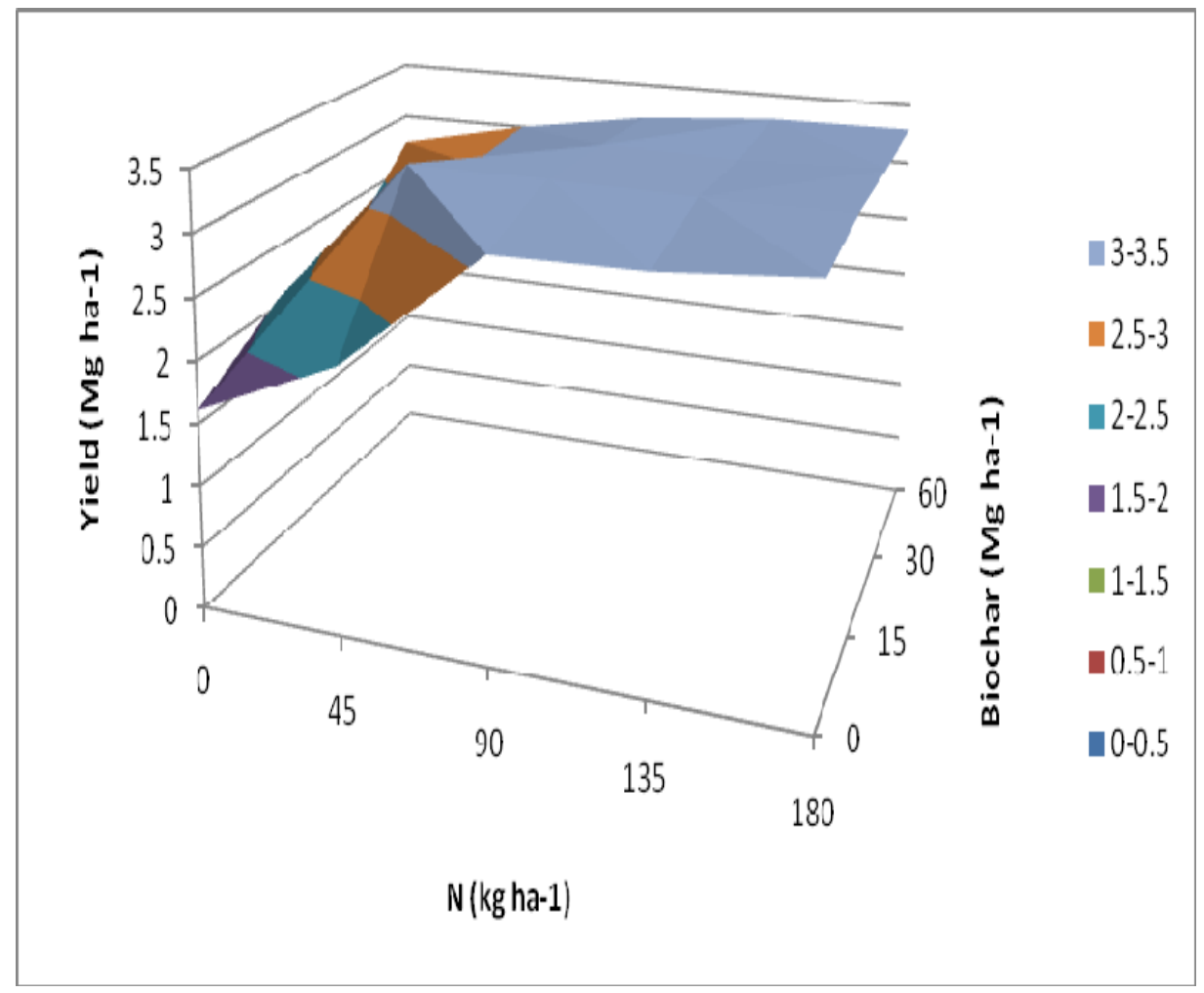

Figure 1. Curve response of maize biomass yield to nitrogen and biochar application 